\title{
CONSTRUCTION AND DEMOLITION WASTE MANAGEMENT IN CROATIA WITH RECYCLING OVERVIEW
}

\section{Gordan Bedeković *, Biljana Kovačević Zelić and Ivan Sobota}

Department of Mining Engineering and Geotechnics, Faculty of Mining, Geology and Petroleum Engineering, University of Zagreb, Pierottijeva 6, 10000 Zagreb, Croatia

Article Info:

Received:

15 June 2018

Revised:

23 October 2018

Accepted:

9 November 2018

Available online:

21 November 2018

Keywords:

Construction waste

Demolition waste

Waste management

Recycling

C\&D waste

\section{ABSTRACT}

Construction and demolition waste (C\&D waste) is one of the most relevant waste types primarily due to large quantities and a high potential for re-use and recycle. This paper discusses the issues related to C\&D waste management in the Republic of Croatia. It presents the overview of legislative changes and its impact on the C\&D waste management in Croatia. C\&D waste quantities per county in the period from 2001 to 2015 are given as well as the expected C\&D waste quantities in the future. It is concluded that the legal framework is well established, but it is not implemented consistently. Therefore, it is necessary to plan certain activities and additional resources in order to make the C\&D waste management more efficient. The paper also presents the options of C\&D waste recycling and describes the recycling technology in a C\&D waste recycling plant in the Republic of Croatia. Taking into account the relatively low price of recycled aggregate, long distance transport is not profitable. It is concluded that the use of mobile treatment facilities would be a good practical solution taking into account the underdeveloped infrastructure for C\&D waste management.

\section{INTRODUCTION}

One of the major problems related to environmental protection in the Republic of Croatia is inadequate waste management. The quantity of waste is increasing, and the existing infrastructure is not sufficient (Official Gazette, 2017a). In addition to that, a major problem is a partial implementation of the regulations related to the waste management. The waste management sector is exceptionally important for the Republic of Croatia due to numerous reasons. The most important among them is a potential harmful effect on the environment (water, air and soil), on the quality of life and human health, plants and animals, affecting the attraction of Croatia as a tourist destination, as well as the international perception of Croatia as a country of preserved environment and healthy food production. In 2014 Croatia generated 3.7 million tonnes of waste, $3 \%$ of which is hazardous waste and $97 \%$ non-hazardous waste (Official Gazette, 2017a). Taking into account the source of waste, the largest part of $31 \%$ was generated in households (municipal solid waste and similar), 17\% through commercial sources (various trades/crafts, insurance, brokerage, administration, cleaning, etc), $17 \%$ in the construction sector, $12 \%$ in manufacturing, $11 \%$ through collection, treatment, disposal and recovery operations and $12 \%$ through other commercial and industrial activities
(Official Gazette, 2017a). If we analyse waste treatment in $2014,56 \%$ of waste was deposited in landfills and $44 \%$ was processed, $40 \%$ of which for material recovery, $2 \%$ for energy recovery and up to $2 \%$ was treated by backfilling (Official Gazette, 2017a). Compared to the year 2012 the results demonstrate the decrease of $10 \%$ in disposal and the increase of $8 \%$ in recovery (Official Gazette, 2017a).

The prerequisite for solving the problem related to the waste management and raising the efficiency of waste management system is the creation and improvement of an appropriate legal framework. After the accession to the EU, Croatia is continuously harmonizing its legislation with EU legislative acts. According to the Act on Sustainable Waste Management (Official Gazette, 2013), C\&D waste is the waste resulting from new construction, reconstruction, demolition and maintenance of existing buildings, as well as any excavation waste which cannot be used without prior recovery for the purposes of construction for which it was excavated. Taking into consideration the way it is generated, it includes demolition waste, road construction and maintenance waste, soil, stone and vegetation.

It is estimated that the C\&D waste has a high potential for recycling and a high economic value and that $80 \%$ of the C\&D waste can be re-used in China (Zheng et al., 2017). The Waste Framework Directive 2008/98/EC aims 
to have $70 \%$ of C\&D waste recycled by 2020 in EU. This will be achieved by improved waste identification, source separation and collection, improved waste logistics, improved waste processing, quality management, appropriate policy and framework conditions. The C\&D waste is recognized as one of priority waste streams at the European level. Officially available data on generated C\&D waste and the capacity for its treatment in the Republic of Croatia are not entirely comprehensive and reliable. According to the official data of the Croatian Agency for the Environment and Nature in the period 2011-2013, the registered quantities of the generated C\&D waste were below $200 \mathrm{~kg}$ per capita. The growth rate of the registered quantities was recorded in relation to the registered quantities in the aforementioned period when they were below $200 \mathrm{~kg}$ per capita. Taking into consideration the actual growth of the construction sector in the Republic of Croatia until 2008 and its decline after 2008 due to the recession, the growth of the registered quantities (Table 1) can be primarily attributed to the improved data collection and processing system, as well as possible methodology differences in classification. Difficulties in determining quantities of the generated C\&D waste are not present only in the Republic of Croatia, but also in other EU member states. One of the conclusions of the topic-related project "Management of construction and demolition waste" was that the methodology for determining quantities and composition of the C\&D waste was not entirely harmonized at EU level, and the available data were not completely reliable (European Commission, 2011). It was concluded that all member states that in 2004 registered the quantities substantially lower than the average of EU member states (940 kg per capita), had underestimated their quantities of generated C\&D waste. It indicated the importance of recognizing the C\&D waste as one of priority categories of waste and the need to create prerequisite for the efficient C\&D waste management in the following period.

C\&D waste is related primarily to the construction sector, but also to mining operations. The mining sector is the main provider of primary raw materials and products necessary for construction operations, and at the same time it has to manage large quantities of its own, very

TABLE 1: Quantities of collected C\&D waste in the Republic of Croatia (Croatian Agency for the Environment and Nature, 2017).

\begin{tabular}{c|c} 
Year & C\&D Waste (t) \\
\hline 2006 & 275323 \\
\hline 2007 & 266457 \\
\hline 2008 & 194456 \\
\hline 2009 & 131863 \\
\hline 2010 & 362567 \\
\hline 2011 & 579240 \\
\hline 2012 & 717382 \\
\hline 2013 & 872782 \\
\hline 2014 & 761312 \\
\hline 2015 & 882256
\end{tabular}

similar waste. Mining engineering in Croatia is mainly oriented to oil and gas exploitation, and non-metallic mineral resources exploitation. Approximately 200 companies are engaged in non-metallic mineral resources exploitation, $50 \%$ of which in the exploitation of aggregate resources, $20 \%$ in sand and gravel exploitation, $30 \%$ in the exploitation of clay, raw materials for cement and lime, dimension stone, quartz and sea salt production (Salopek and Bedeković, 2001). The consumption of stone material in the City of Zagreb amounts to 2.5 million cubic meters per year, which is approximately $25 \%$ of average annual production of stone material in the Republic of Croatia, $20 \%$ of which is provided from sources in the City of Zagreb and $60 \%$ from Zagreb county (Salopek et al., 2003). Taking into account the increasing pressure on mining operations due to environmental protection, the recycling of C\&D waste presents a huge and insufficiently used potential.

\section{LEGISLATION DEVELOPMENT AND ITS IMPACT ON THE C\&D WASTE MANAGEMENT IN THE REPUBLIC OF CROATIA}

The C\&D waste management in the Republic of Croatia is regulated by various strategic and legal documents and plans (Figure 1). Inadequate waste management was recognized as the major problem in environmental protection in the Republic of Croatia both by National Environmental Protection Strategy (Official Gazette, 2002a.) and by National Environmental Action Plan (Official Gazette, 2002b.). They predicted waste management crisis due to the increasing quantities of waste and insufficient infrastructure unless significant changes were introduced soon. Inadequate waste management system negatively affects the environment, particularly groundwater, which is the main source of drinking water and a basic national resource.

Waste Act from 2004 (Official Gazette, 2004) introduced waste management permits (collection, recovery, disposal) that companies had to obtain, and its amendments from 2008 and 2009 introduced the concepts of the C\&D waste recycling yards and concession contracts for waste management operations based on public tenders.

Waste Management Strategy of the Republic of Croatia from 2005 (Official Gazette, 2005b) defined the framework for sustainable waste management in relation to the evaluation of the current status, basic objectives and measures for hazardous and non-hazardous waste management, and guidelines for waste recovery and disposal. In the part referring to the C\&D waste, the Strategy aimed at $80 \%$ C\&D waste recovery. It proposed the conversion of sanitary landfills to inert waste landfills, treatment and disposal of the C\&D waste next to waste management centres with mobile or stationary treatment facilities. The total annual quantity of C\&D waste was estimated at 2.6 million t. It includes 1 million t/annually of construction waste and 1.6 million t/annually of waste generated during road construction and development projects, tailings generated by the extraction of mineral resources, demolition waste and the waste resulting from military destructions. The construction waste was composed of $75 \%$ of excavation 
material, construction and demolition debris accounts for $15-25 \%$, while the asphalt, tar and concrete account for 5 $10 \%$. It is mostly inert waste (95\%): fragments of ceramics, mortar, plaster, broken concrete, iron, steel, metals, wood, plastic material, paper, etc.) (Official Gazette, 2005b).

Waste Management Plan in the Republic of Croatia for the period from 2007 to 2015 (Official Gazette, 2007) anticipated the possibility of pre-treatment of the C\&D waste in transfer stations and treatment at existing landfills until waste management centres were established. Based on a concession contract, mobile treatment facilities would be used and concession holders would be responsible. Recycling was encouraged by proposing a fee for the acceptance of C\&D waste for recovery ranging from 5 to $15 € / t$, substantially lower than the waste disposal charge. Market principles will apply to the price of recycled aggregate.

Ordinance on construction waste management (Official Gazette, 2008) defines participants in the C\&D waste management and their relations and obligations. According to the Ordinance, the recovery of C\&D waste is carried out in mobile treatments facilities at its source, and in stationary treatment facilities in the C\&D waste recycling yards.

Act on Sustainable Waste Management (Official Gazette, 2013) defined waste management sites and waste disposal charges in order to stimulate recovery/recycling and reduce disposal in landfills.

One of the last documents is the Waste Management Plan in the Republic of Croatia for the Period from 2017 to 2022 (Official Gazette, 2017a). It set out objectives for recycling i.e. material recovery by the year 2020 (70\%). Another objective is to collect $75 \%$ of the amount of generated C\&D waste.

In addition to that, the waste management system is regulated by various ordinances like: Ordinance on Classification of Waste (Official Gazette, 1996), Ordinance on
Waste Management (Official Gazette, 2017b), Ordinance on Conditions for Waste Management (Official Gazette, 1997), Regulation on categories, types and classification of waste with a waste catalogue and list of hazardous waste (Official Gazette, 2005a), Regulation on conditions on the handling of hazardous waste (Official Gazette, 1998) and Regulation on transboundary waste movement (Official Gazette, 2006).

After its accession to the EU, Croatia assumed the obligations resulting from various EU directives related to the area of waste management. Waste disposal according to hierarchy (avoiding - reducing - recycling - energy recovery) with the development of appropriate network for waste collection and processing and "the polluter-pays principle" is prescribed by the Directive 2006/12/EC on waste (European Commission, 2006a). The classification of landfills and waste, the handling of waste intended for landfill and the types of waste to be accepted in the various classes of landfill, specific permits and the management of landfill sites are prescribed by the Council Directive 1999/31/ec on the landfill of waste (European Commission, 1999), while the issues of monitoring and the environmental impact assessment are regulated by the Council Directive 85/337/ EEC on the assessment of the effects of certain public and private projects on the environment (European Commission, 1985). Council Directive 91/689/eec on hazardous waste (European Commission, 1991) defines the properties of hazardous waste, prohibits mixing hazardous waste with non-hazardous waste, sets the procedures for the handling of waste already mixed with other waste, substances or materials, regulates drawing up plans for the handling of hazardous waste, permit issuing, record keeping etc. in the member states, and it is amended by the Council Directive 94/31/EC and Commission Decision 2000/532/EC. Council Directive $87 / 217 /$ EEC on the prevention and reduction

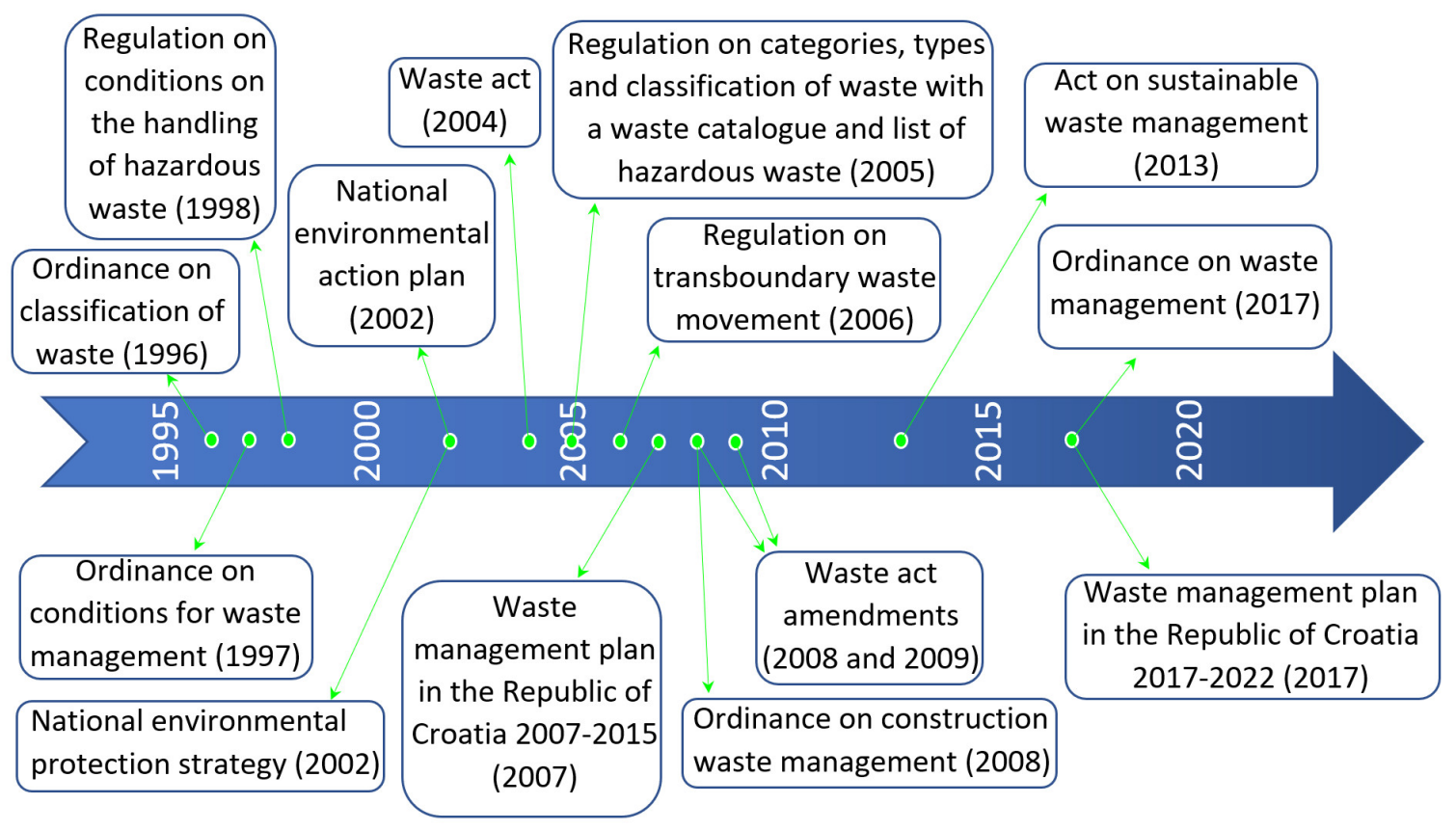

FIGURE 1: The timeline of the Croatia's legislation development. 
of environmental pollution by asbestos (European Commission, 1987) joins supervision of emissions into the air and water, and defines procedures and conditions related to recycling and disposal of asbestos, as well as the monitoring methods for emissions into the air and water. It is amended by the Council Directive 91/692/EEC and Council Regulation (EC) No 807/2003. We also have to mention Directive 2006/21/EC on the management of waste from extractive industries (European Commission, 2006b) that gives guidelines, measures and procedures with the aim of minimizing negative impact on human health and environment in the waste management related to excavation, mineral processing and storage of mineral resources and the operations in quarries. This Directive sets the obligation of drawing up a waste management plan and its minimum requirements, and classifies waste facilities as Category $A$ (presents a serious risk of major accidents in a case of a failure or incorrect operation), and Category B (all the other waste facilities).

\section{C\&D WASTE RECYCLING IN THE REPUBLIC OF CROATIA}

The C\&D waste recycling saves primary (mineral) resources and reduces the quantity of waste intended for landfill. It saves energy, therefore reducing emissions in

TABLE 2: Estimated annual quantities of C\&D waste in the Republic of Croatia (Bjegović, 2008).

\begin{tabular}{|c|c|c|}
\hline Country & $\begin{array}{l}\text { Estimated average } \\
\text { annual quantities } \\
\text { of C\&D waste } \\
2001-2005(t)\end{array}$ & $\begin{array}{c}\text { Estimated average } \\
\text { annual quantities } \\
\text { of C\&D waste } \\
2006-2015(t)\end{array}$ \\
\hline City of Zagreb & 140175 & 581297 \\
\hline Split-Dalmatia & 138865 & 283767 \\
\hline Primorje-Gorski Kotar & 113329 & 246131 \\
\hline Istria & 76544 & 166242 \\
\hline Osijek-Baranja & 109164 & 112422 \\
\hline Zagreb & 78992 & 111026 \\
\hline Zadar & 48530 & 99170 \\
\hline Dubrovnik-Neretva & 36798 & 75195 \\
\hline Vukovar-Srijem & 67633 & 69652 \\
\hline Šibenik-Knin & 33809 & 69088 \\
\hline Sisak-Moslavina & 47285 & 66461 \\
\hline Varaždin & 47127 & 66240 \\
\hline Slavonski Brod-Posavina & 58384 & 60127 \\
\hline Krapina-Zagorje & 36329 & 51062 \\
\hline Karlovac & 36164 & 50830 \\
\hline Bjelovar-Bilogora & 43956 & 45269 \\
\hline Koprivnica-Križevci & 31746 & 44621 \\
\hline Lika-Senj & 19911 & 43245 \\
\hline Međimurje & 30206 & 42455 \\
\hline Virovitica-Podravina & 30845 & 31766 \\
\hline Požega-Slavonija & 28349 & 29195 \\
\hline TOTAL & 1254141 & 2344901 \\
\hline
\end{tabular}

energy production, and the result is a lower environmental impact (Ulubeyli et al., 2017). The process of recycling omits the phase of excavation of mineral resources and the other phases of a technological process are very similar. The EU recycles approximately $60 \%$ of C\&D waste, but with huge differences among individual member states (from $10 \%$ to $90 \%$ ). Five member states have met the objective of $70 \%$ re-use and recycling of the C\&D waste set by the Directive 2008/98/EC (European Commission, 2008): the Netherlands 98.1\%, Denmark 94.9\%, Estonia 91.9\%, Germany $86.3 \%$ and Ireland $79.5 \%$ (Ulubeyli et al, 2017). USA, South Korea and Japan have a high level of recycling, ranging from $70 \%$ to $95 \%$ (Huang et al., 2018). Compared to the aforementioned results, the Republic of Croatia has to invest additional effort. It is estimated that Croatia generates 2.5 million tonnes/annually of C\&D waste, while only $7 \%$ of that amount is recycled (Bjegović, 2008). The largest part of a total amount is generated in the City of Zagreb (Table 2). Therefore the only stationary treatment facility is situated in the city of Zagreb, while in the other parts of Croatia recycling is carried out in mobile processing plants. The C\&D waste in the City of Zagreb consists mainly of soil and stone (93\%), metal (6\%), mixed C\&D waste (1\%), concrete, brick, tiles and plaster material (up to 0,1\%) (Bjegović, 2008). The recycling technology in the stationary treatment facility is determined according to the composition of generated C\&D waste (Figure 2).

The construction and demolition waste recycling plant in Zagreb (Figure 2) consists of two parts: primary and secondary. The C\&D waste is transported by trucks to the plants storage plateau and it is loaded to the storage bunker (1). Below the bunker, there is a mechanical feeder which doses waste to the grade (4) with interspace profiles of 400 $\mathrm{mm}$. Oversize (grain size $+400 \mathrm{~mm}$ ) should be comminuted by hydraulic hammer, while undersize (grain size $-400 \mathrm{~mm}$ ) goes to the rougher separation into (first) magnetic separator (8), where Fe is separated as a final product. Rest of the waste goes to a jaw crusher for the primary crushing (2). After the primary crushing Fe is separated in the scavenging 1 (second magnetic separator) (9) and the rest of the waste goes to an impact crusher for the secondary crushing (3). After the secondary crushing stage, $\mathrm{Fe}$ is separated in the scavenging 2 (third magnetic separator) (10) while the rest of the waste goes to the screening. The screening section consists of two stages. In the first stage, the waste goes to the vibration screen (5) with openings of $100 \times 100 \mathrm{~mm}$. This vibration screen (5) works in a closed circle with the jaw crusher, so screen oversize $(+100 \mathrm{~mm})$ go once again to a jaw crusher for crushing (2), while undersize ( -100 $\mathrm{mm})$ goes to the secondary screening stage which consists of two vibrating screens $(6,7)$. By adjusting a material flow router (11) it is possible to use two different vibrating screens in a secondary screening stage. If the material flow router (11) is set to use the first vibrating screen (6) with hole size of $63 \mathrm{~mm}$, then grain size 100/63 mm (screen oversize) and grain size $-63 \mathrm{~mm}$ (screen undersize) go to the dump as final products. If the material flow router (11) is set to use the second vibrating screen (7) then grain size $100 / 31.5 \mathrm{~mm}$ (screen oversize) and grain size $-31.5 \mathrm{~mm}$ go to the dump as final products. An integral part of the recy- 


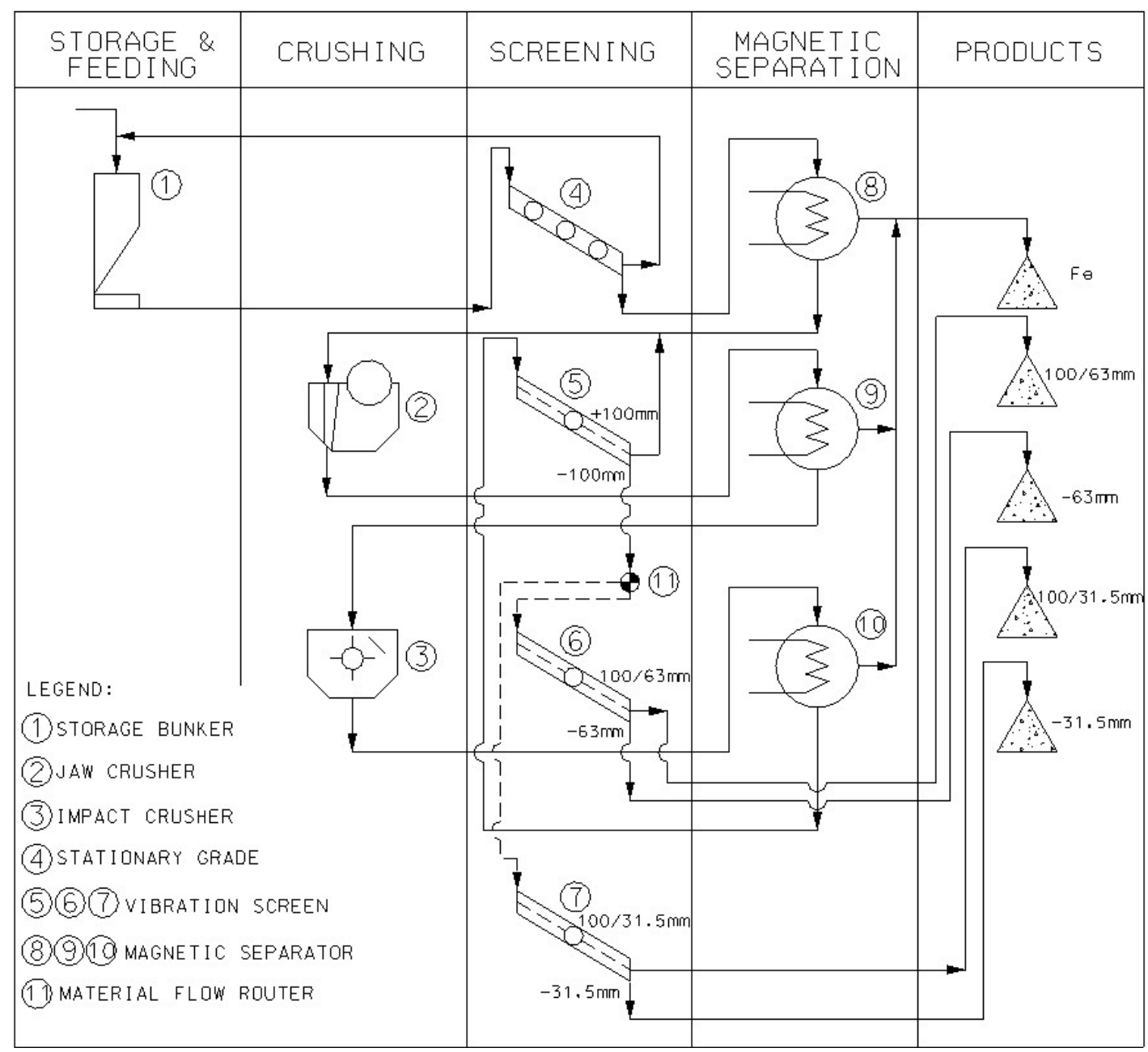

FIGURE 2: The flow sheet of the C\&D waste recycling plant.

cling plant is a dedusting system. All belt conveyors are covered to prevent dust spreading into the surrounding area. Secondary, the impact crusher (3) and all vibrating screens $(5,6,7)$ are included in the dedusting system. The polluted air from the crusher and vibrating screens is led by tubes into the bag filter for cleaning. The efficiency of the bag filter is more than $99 \%$ and the clean air is let out through the chimney to the atmosphere. Dust particles remain in the bag filter and are collected in the dust collector below the bag filter. In addition, the recycling plant is equipped with watersprinklers.

Inadequately developed C\&D waste recycling is the consequence of insufficient knowledge, as well as the insufficient awareness of the importance and advantages of the use of recycled material in environmental protection and preservation of natural resources, low level of understanding of possibilities of use of those materials, lack of experience, underdeveloped market, inadequate quality standards, variable prices and technical regulations (Bjegović, 2008). A prerequisite for a successful development of recycling as an unavoidable segment of the C\&D waste management is a legal, economic and technological framework.

The composition of C\&D waste largely depends on the fact whether a new structure is being constructed or an existing one is being demolished. Furthermore, the geographic features of Croatia influence the composition of C\&D waste. If the composition of C\&D waste in four major regions of Croatia is observed, stone prevails in two of the regions (Dalmatia and Primorje), while in the east of Croatia the C\&D waste mostly consists of bricks, i.e. mixed waste, while concrete and brick prevail in the northeast. The composition and quantity of waste partly influence recycling technology. The process may be simpler or more complex, depending on the raw material to be recycled, as well as on the planned use of the recycled material. The secondary raw material, obtained through C\&D waste recycling, is mostly used as a material for load-bearing layer for roads and added to asphalt concrete mixtures and different types of concrete.

\section{RESULTS AND DISCUSSION}

On the basis of systemized data on collected C\&D waste within LIFE05 TCY/CRO/000114 CONWAS project (Bjegović, 2008), the average quantity of C\&D waste is calculated for all counties in Croatia for two previous periods (2001-2005 and 2006-2015). 
The estimated quantities of C\&D waste in the period 2006 - 2015 included a larger part of C\&D waste at so-called uncontrolled landfills, and the intense demolition of old structures along the Adriatic coast in that period, as well as decreasing waste from the war affected areas. The quantities for the period 2001-2005 are based on the data obtained by questionnaires, and the actual quantities for the period 2001-2005 are definitely larger than the ones obtained through questionnaires.

Taking into account the current legal framework for C\&D waste management, and based on the indicators of the Croatian Bureau of Statistics on the value of performed construction and demolition operations, a significant increase in the quantities of C\&D waste is not expected in the following years. Based on the aforementioned data, it is estimated that the annual increase rate will amount to $1.5 \%$ by 2020 . According to that estimate, a total amount of C\&D waste will amount to $1,281,231$ tonnes and non-hazardous mineral waste to 539,861 tonnes by 2020 (Štirmer and Škreb, 2017).

The aforementioned discussion points to the fact that all documents include "estimated" and not "actual" quantities of the C\&D waste. Without high-quality data on quantities, composition, sources and waste streams it is not possible to plan and establish efficient logistics, appropriate technology for sorting and recycling, or to design landfills. Therefore, it is necessary to ensure continuous and high-quality data collection in order to draw up plans, strategies and to establish efficient C\&D waste management. Collection and transport of C\&D waste is mostly carried out by contractors with their co-operators, using their own equipment, and only a smaller part is carried out by authorized collectors and utility companies. According to the data of the Croatian Agency for the Environment and Nature, a total of $136 \mathrm{com}-$ panies in the Republic of Croatia have a permit for the C\&D waste management. Although the Ordinance on Classification of Waste prescribes registers for waste handling (type, quantity, source, handling) and transfer notes certified by a waste producer, collector and treater, the systematic monitoring of quantities, properties and waste streams has not been established yet, therefore the quantities of C\&D waste can only be estimated.

Since the C\&D waste is not always registered under the correct catalogue number, and some construction companies and quarries recycle C\&D waste in their own facilities, and the C\&D waste is occasionally disposed in uncontrolled landfills with other waste, it is not possible to determine actual quantities and composition of C\&D waste. Despite relatively good legal framework and regulations, it is necessary to invest additional efforts into their consistent implementation in order to improve the current state. The importance to the issue of the C\&D waste management is given by exceptionally large quantities of that waste that proportionally increase the problem in the case of inappropriate handling. Some of the problems still waiting to be solved are uncontrolled disposal of C\&D waste, lack of separation system at the source or in sorting centers, mixing hazardous and non-hazardous waste, ignoring C\&D waste issues during the design of the building and low level of communication between participants included in the C\&D waste management process.

\section{CONCLUSIONS}

The importance of C\&D waste management is the result of its large quantities compared to other types of waste, and its high potential for recycling. Additionally, besides the impact on the environment as a whole, plants and animals, the adequate waste management in the Republic in Croatia is important for keeping the international perception of the country of preserved environment and attraction as a tourist destination. In order to make waste management efficient, it is necessary to establish an efficient waste management system. A prerequisite for efficient waste management is an adequate legal framework. Croatia progressed a lot during the last 15 years, and after the accession to the EU, it assumed the obligations resulting from various EU directives. In addition to that, numerous studies and projects related to the C\&D waste management issues have been carried out, but they are all based on estimated quantities of waste. The essential prerequisite for the efficient waste management is data on actual quantities, types and waste streams of the C\&D waste. The registered quantities of the C\&D waste at the county level, which are obviously lower than the actual quantities, emphasise the weakness of the system, particularly in less developed areas. Therefore, it is essential to invest additional efforts with the goal of high-quality monitoring of quantities, composition and C\&D waste streams as a basis for planning technologies, plants and facilities for C\&D waste management. Legal framework is relatively well established, but it is not entirely implemented, and we have to insist on its implementation in the future. In addition to the advantages of recycling compared to the exploitation of primary raw materials in the production of aggregates, the success of the C\&D waste recycling will depend on its market value, i.e. the difference in the price of recycled and natural aggregates, as well as on the waste disposal costs. Taking into consideration the quantities of waste and inadequate infrastructure for C\&D waste management, mobile treatment facilities seem to be the best option for solving the C\&D waste management issues in Croatia.

\section{ACKNOWLEDGEMENTS}

This research was supported by the Development fund of the University of Zagreb, through the project "The usage of recycled plastics for the improvement of engineering soil properties". This support is gratefully acknowledged.

\section{REFERENCES}

Bjegović, D.; Mikulić, D.; Štirmer, N.; Prutki Pečnik, G. (2006): Development of Construction and Demolition Waste Management System for Croatia. Ninth International Symposium Waste Management, 109-118.

Bjegović, D. (2008). Project LIFE05 TCY/CRO/000114 CONWAS - Development of sustainable construction and demolition waste management system for Croatia, Faculty of Civil Eng. Croatia. 
Croatian Agency for the Environment and Nature (2017). Improvement of flow and quality of data on construction waste and waste from exploration and exploitation of mineral substances in the Republic of Croatia - Estimation of construction waste amount and the potential for its use.

European Commission (1985). Directive 85/337/EEC on Environmental Impact Assessment.

European Council (1987). Directive 87/217/EEC on the prevention and reduction of environmental pollution by asbestos.

European Commission (1991). Directive 91/689/EEC on hazardous waste.

European Commission (1999). Directive 1999/31/ec on the landfill of waste.

European Commission (2006a). Waste Framework Directive 2006/12/ EC.

European Commission (2011). Project - SERVICE CONTRACT ON MANAGEMENT OF CONSTRUCTION AND DEMOLITION WASTE - SR1, A project under the Framework contract ENV.G.4/FRA/2008/0112, Final Report Task 2, February 2011.

European Parliament and Council (2006b). Directive 2006/21/EC on the management of waste from extractive industries.

European Commission (2008). Waste Framework Directive 2008/98/ EC.

Huang B., Wang X., Kua H., Genge Y., Bleischwitz R., Ren J. (2018). Construction and demolition waste management in China through the 3R Principle. Resources, Conservation \& Recycling, vol. 129, 36-44.

Official Gazette (1996). Rule book on the waste Types. Official Gazette of the Republic of Croatia issue no. 27 of April 4th, 1996.

Official Gazette (1997). Rule book on the Waste Treatment Conditions. Official Gazette of the Republic of Croatia issue no. 123 of November 19th, 1997.

Official Gazette (1998). Regulation on Conditions for the Treatment of Hazardous Waste. Official Gazette of the Republic of Croatia issue no. 32 of March 10th, 1998.

NN (2002a). National Environment Strategy. Official Gazette of the Republic of Croatia issue no. 46 of January 25th, 2002.

NN (2002b). National Action Plan on the Environment. Official Gazette of the Republic of Croatia issue no. 46 of April 29th, 2002.

Official Gazette (2004). Law on Waste. Official Gazette of the Republic of Croatia issue no. 178 of December 16th, 2004.
Official Gazette (2005a). Regulation on categories, types and classification of waste with a waste catalog and a list of hazardous materials. Official Gazette of the Republic of Croatia issue no. 50 of April 18th, 2005

Official Gazette (2005b). Waste Management Strategy of the Republic of Croatia. Official Gazette of the Republic of Croatia issue no. 130 of November 2nd, 2005.

Official Gazette (2006). Regulation on the Transboundary Waste Movement. Official Gazette of the Republic of Croatia issue no. 69 of June 21st, 2006.

Official Gazette (2007). Waste Management Plan in the Republic of Croatia 2007-2015. Official Gazette of the Republic of Croatia issue no. 85 of August 16th, 2007.

Official Gazette (2008). Rule book on the Management of construction waste. Official Gazette of the Republic of Croatia issue no. 38 of April 2nd, 2008.

Official Gazette (2013). The Law on Sustainable Waste Management. Official Gazette of the Republic of Croatia issue no. 94 of July 22nd, 2013.

Official Gazette (2017a). Waste Management Plan in the Republic of Croatia 2017-2022. Official Gazette of the Republic of Croatia issue no. 3 of January 1st, 2017.

Official Gazette (2017b). Rule book on the Waste Management. Official Gazette of the Republic of Croatia issue no. 117 of November 29th, 2017.

Salopek, B., Bedeković, G. (2001). Safety Measures in Technical Stone Quarries. Work and Safety, vol. 5, 141-166.

Salopek, B., Sobota, I., Bedeković, G. (2003). Production of Construction Aggregates in Urban Areas. Proceedings of the International Conference on Sustainable Development Indicators in the Mineral Industries (SDIMI 2003), 273-278.

Štirmer, N., Škreb, K.A. (2017). Improving the flow and quality of data on C\&D waste, exploration and exploitation of mineral resources in the Republic of Croatia - Estimated quantities of C\&D waste and the potential for its use. Faculty of civil engineering, Zagreb, pp 86 (in Croatian)

Ulubeyli S., Kazaz A., Arslan V. (2017). Construction and demolition waste recycling plants revisited: management issues. Procedia Engineering 172, $1190-1197$

Zheng L., Wu H., Zhang H., Duan H., Wang J., Jiang W., Dong B., Liu G., Zuo J., Song Q. (2017). Characterizing the generation and flows of construction and demolition waste in China. Construction and Building Materials, vol. 136, 405-413. 